\title{
Assessment of genetic diversity in Indian Barnyard millet (Echinochloa spp. complex) using morphological and molecular markers
}

\author{
M. P.Moharil ${ }^{1}$, Dipti Gawai ${ }^{1}$, N. Dikshit ${ }^{2 *}$, M.S. Dudhare ${ }^{1}$ and P. V. Jadhav ${ }^{1}$ \\ ${ }^{1}$ Biotechnology Centre, Dr. Panjabrao Deshmukh Agricultural University, Akola-444104 (Maharashtra), INDIA \\ ${ }^{2}$ ICAR-National Bureau of Plant Genetic Resources, Dr.PDKV campus, Akola-444104 (Maharashtra), INDIA \\ *Corresponding author. E-mail: dikshitn@gmail.com
}

Received: December 27, 2015; Revised received: June 14, 2016; Accepted: August 24, 2016

\begin{abstract}
In the present study, morphological and molecular markers (RAPD primers) were used to analyze the genetic diversity and genetic relationships among 21 accessions of Echinochloa spp. complex comprising the wild and cultivated species collected from Melghat and adjoining regions of Vidarbha, Maharashtra. The availability of diverse genetic resources is a prerequisite for genetic improvement of any crop including barnyard millet. A high degree of molecular diversity among the landraces was detected. Among the 21 genotypes, two major groups (A and B) were formed, at $67.28 \%$ similarity, which clearly encompasses 15 accessions of $E$. frumentacea and 6 accessions of $E$. colona. Higher similarity was observed in accessions of $E$. frumentacea. The accessions IC 597322 and IC 597323 also IC 597302 and IC 597304 showed more than 94\% similarity among themselves. The classification of genetic diversity has enabled clear-cut grouping of barnyard millet accessions into two morphological races (E. frumentacea and E. colona).
\end{abstract}

Keywords: Barnyard millet, Genetic diversity, Genetic relationship, RAPD marker

\section{INTRODUCTION}

Barnyard millet, Echinochloa sp. $(2 n=36,54)$ is a self pollinating crop which belongs to family Poaceae and is grown as cereal or fodder crop. It is one of the oldest domesticated millets in the semi-arid tropics of Asia and Africa (Holm et al. 1977). The genus comprises approximately 50-60 species (Michael 1994) and includes important native species (Watson and Dallwitz 1992), species cultivated as fodder and grain crops, and significant weed species such as E. crus-galli ( barnyard grass) and E. colona ( awnless barnyard grass) (Holm et al. 1977). Echinochloa utilis is a temperate annual hexaploid $(2 \mathrm{n}=6 \mathrm{x}=54)$ and is cultivated in Japan, Korea etc. E. frumentacea $(2 \mathrm{n}=36,54)$ is cultivated in India, Pakistan and Nepal (Yabuno, 1962). The wild ancestor of Echinochloa frumentacea is the tropical grass Echinochloa colona (L.) Link. Barnyard millet is the fastest growing crop among all millets and can be harvested in a short period of nine weeks. Its grains contain $11.2(\mathrm{~g})$ protein, $10.1(\mathrm{~g})$ crude fiber, 4.4(g) minerals, 15.2(mg) Iron, $11(\mathrm{mg})$ calcium per 100gm grain (MINI, India). Also it is a nutritive fodder for animals. Studies on nutrient composition, glycaemic index and health benefits of barnyard millets indicated that it is beneficial for type-II diabetes (Ugare et al., 2011). The crop is valued for its drought tolerance, good yield and superior nutritional value. Study of biodiversity and available natural resources are essential for identifying genotypes having higher yield potential without compromising on the nutritional front. Measurement of genetic diversity also allows the estimation of important population parameters e.g., characterization of the geographic structure or connectivity of populations (Gupta et al., 2009). Molecular traits have virtually no environmental component and large numbers of variables are produced. As a result, qualitative and quantitative traits can be more efficiently introduced into plant breeding programmes. One technique which can provide useful data for the comparison of plant types is random amplified polymorphic DNA (RAPD) analysis. This is a modified PCR technique involving the amplification of wholeplant DNA extracted from leaves or other plant organs. In the RAPD technique, multiple 10 base pair (bp) oligonucleotide primers are added each to an individual sample of DNA which is then subjected to PCR. This technique is sensitive, fast, requires the use of no radioactive probes, and is easily performed. In the present paper, an attempt has been made to assess the genetic diversity in Indian Barnyard millet (Echinochloa frumentacea (Roxb.) Link) and its progenitor wild species (E. colona (L.) Link) from Melghat Biosphere Reserve using morphological and molecular markers.

\section{MATERIALS AND METHODS}

Plant material: During a survey and exploration programme during $29^{\text {th }}$ October $-5^{\text {th }}$ November 2012, a total of 21 accessions of barnyard millet and their wild relatives were collected (Table 1). The passport data 
(place of collection i.e. village, block, latitude, longitude, altitude) and vernacular name of the species collected are mentioned (Table 2).Two sets of different accessions of both the species (E. frumentacea and E. colona) were examined. 15 accessions of $E$. frumentacea and 6 accessions of $E$. colona were used for the study.

Morphological characters: All the 21 genotypes were sown in the fields in a Randomized Block Design (RBD) at ICAR-National Bureau of Plant Genetic Resources Regional Station, Dr.PDKV campus, Akola (Maharashtra) for two consecutive years 2012 and 2013. Crop management was done according to the recommended agronomic practices (N:P:K 40:20:0). Sowing was done in the plots $(3 \mathrm{~m} \times 1 \mathrm{~m})$, plant to plant distance was maintained at $10 \mathrm{~cm}$, while row to row distance was kept at $30.0 \mathrm{~cm}$. Various morphological characters including, plant height, leaf length, leaf width, flag leaf length, flag leaf width, inflorescence length, inflorescence width, number of racemes / inflorescence, raceme length, color of inflorescence, days to maturity, inflorescence shape, inflorescence compactness, shape of lower raceme, length of peduncle, arrangement of spikelet, degree of branching, degree of lodging and 100 seed weight were taken to assess genetic variability in accessions.

DNA isolation and PCR amplification: Seeds were grown in the green house and leaf material was harvested from 3-4 week old seedlings. Total cellular DNA was isolated from leaf material of individual plants following the procedure of Doyle and Doyle (1987, 1990) using CTAB with few modifications.

Measurement of DNA purity and quality: The quantity of DNA was measured using a UV Spectrophotometer at $260 \mathrm{~nm}$. The purity of DNA was determined by calculating the ratio of absorbance at $260 \mathrm{~nm}$ to that of $280 \mathrm{~nm}$ (Sambrook et al.,1989).The DNA concentration was determined by the formula: DNA concentration $=$ OD260 $\times 50 \mu \mathrm{g} / \mathrm{ml} \times$ dilution factor (Linacero et al.,1998).

Screening of RAPD primers: Decamer oligonucleotides were used in this study. 20 RAPD primers (Table 3) were screened for polymorphism. Primers that gave clear and polymorphic profiles were chosen for further study.

DNA amplification of selected primers: DNA samples for PCR amplification were diluted to $30 \mathrm{ng} / \mu \mathrm{l}$ with T.E buffer. Twenty random decamer primers were used to study polymorphism. Out of these, 11 primers gave polymorphic bands and were used for further study.

The PCR amplifications were carried out in a $25 \mu \mathrm{l}$ reaction mixture containing $30 \mathrm{ng}$ of genomic DNA, $0.5 \mathrm{uM}$ primer, $1 \mathrm{X}$ PCR reaction buffer (Invitrogen), $1.5 \mathrm{mM} \quad \mathrm{MgCl}_{2}$ (Fermentas), $0.2 \mathrm{mM}$ dNTP mix (Fermentas) and 1 U Taq polymerase (Invitrogen). Amplifications were carried out in a thermal cycler (Veriti, Applied Biosystems), programmed for one initial denaturation $95^{\circ} \mathrm{C}$ for $5 \mathrm{~min}$. followed by 40 cycles of $92^{\circ} \mathrm{C}$ for $1 \mathrm{~min}$., 26.8 to $42.4^{\circ} \mathrm{C}$ depending on primer for $1 \mathrm{~min}$., $72^{\circ} \mathrm{C}$ for $2 \mathrm{~min}$. and synthesis $72^{\circ} \mathrm{C}$ for $7 \mathrm{~min}$.

PCR amplification products were analyzed by electrophoresis on $1.5 \%$ agarose gel stained with ethidium bromide solution $(0.5 \mu \mathrm{g} / \mathrm{ml})$ and run in TBE buffer at $70-80$ Volts. A $1 \mathrm{~kb}$ ladder plus maker (Fermentas) was used as a molecular weight standard. The documentation was done using Gel Doc system (Alpha innotech). Data analysis : Field data for morphological characters was evaluated and represented graphically by plotting a graph of the various characters used for the study.

Molecular data was analyzed from the banding pattern of RAPD markers. The presence of band was scored from the photograph. Only clear and reproducible bands were given consideration. These bands were considered as polymorphic, when they were absent in some sample in frequency greater than $1 \%$ and change in band intensity were not considered as polymorphism. Clear bands were scored as present (1) or absent (0) at particular position or distance migrated on the gel. The data matrix of 1's and 0's been prepared from the scorable bands and was entered into the data analysis package.

The similarity index was used to calculate the genetic distance values and to construct the dendrogram. The dendrogram provides a visual representation of the differences in the population of various accessions. The NTSYS-pc software ver. 2.02 was used to estimate genetic similarities with the Jaccard's coefficient. The matrix of generated similarities was analyzed by the unweighted pair group method with arithmetic average (UPGMA), employing Sequential, Agglomerative, Hierarchical and Nested Clustering (SAHN) clustering module.

Size of fragments in base pairs was detected with the help of $1 \mathrm{~Kb}$ plus ladder (Table 5). Percent polymorphic loci (a locus is defined polymorphic when the frequency of the marker (allele) is <1.) was calculated using the formula:

$$
\text { percent polymorphic loci }=\frac{\text { mumber of polynorphic bonds }}{\text { total mumber of bonds compared }} \times 100
$$

\section{RESULTS AND DISCUSSION}

Estimation of genetic diversity based on morphological characters: During the present study, a wide range of diversity was observed between E. frumentacea and E.colona accessions. The data was analyzed by plotting a column chart of the two species against different morphological characters viz. plant height, leaf length, leaf width, flag leaf length, flag leaf width, inflorescence length, inflorescence width, number of racemes/ inflorescence, raceme length, color of inflorescence, days to maturity, inflorescence shape, inflorescence compactness, shape of lower raceme, length of peduncle, arrange- 
M.P.Moharil et al. / J. Appl. \& Nat. Sci. 8 (3): 1643 - 1648 (2016)

Table 1. Diversity collected in barnyard millet and their wild relatives.

\begin{tabular}{|c|c|c|c|c|c|c|c|}
\hline Crop / grass name & Botanical name & $\begin{array}{l}\text { Biological } \\
\text { status }\end{array}$ & $\begin{array}{l}\text { Chromosome } \\
\text { Number }\end{array}$ & $\mathbf{C K}^{*}$ & $\mathbf{D N}^{3 * 4}$ & $\mathbf{B P}^{* * \pi ;}$ & Total \\
\hline Barnyard millet & Echinochloa frumentacea Link. & Crop & $2 n=36,54$ & 3 & 11 & 1 & 15 \\
\hline Jungle rice & Echinochloa colona (L.) Link. & Wild & $2 \mathrm{n}=18,36,54$ & 3 & 3 & - & 6 \\
\hline
\end{tabular}

${ }^{*} \mathrm{CK}-$ Chikhaldara, ${ }^{* *} \mathrm{DN}-\mathrm{Dharni},{ }^{* * *}$ BP- Balapur (adjoining Melghat)

Table 2. Passport data of Echinochloa species collected from Melghat Biosphere, Maharashtra.

\begin{tabular}{|c|c|c|c|c|c|c|c|c|}
\hline $\begin{array}{l}\mathbf{S} . \\
\mathbf{N}\end{array}$ & $\begin{array}{l}\text { Accession } \\
\text { No. }\end{array}$ & Botanical Name & $\begin{array}{l}\text { Vernacular } \\
\text { Name }\end{array}$ & Village & $\begin{array}{l}\text { Blo } \\
\text { ck }\end{array}$ & Latitude & Longitude & $\begin{array}{l}\text { Alti- } \\
\text { tude(ft) }\end{array}$ \\
\hline 1 & IC 597287 & E.frumentacea & Bhagar & Doma & CK & $21^{\circ} 33^{\prime} 187^{\prime}$ & $77^{\circ} 33^{\prime} 369^{\prime \prime}$ & 2010 \\
\hline 2 & IC 597298 & E.frumentacea & Sawa & Rehetiakheda & $\mathrm{CK}$ & $21^{\circ} 39^{\prime} 16^{\prime \prime}$ & $77^{\circ} 15^{\prime} 776^{\prime}$ & 1045 \\
\hline 3 & IC 597302 & E.frumentacea & Sawa & Kekdabad & $\mathrm{DN}$ & $21^{\circ} \quad 37^{\prime} 01^{\prime \prime}$ & $76^{\circ} 56^{\prime} 44^{\prime \prime}$ & 1001 \\
\hline 4 & IC 597304 & E.frumentacea & Sawa & Kutanga & $\mathrm{DN}$ & $21^{\circ} 42^{\prime} 162^{\prime \prime}$ & $77^{\circ} 05^{\prime} 520^{\prime \prime}$ & 1005 \\
\hline 5 & IC 597307 & E.frumentacea & Safed Sawriya & Chatwavod & $\mathrm{DN}$ & $21^{\circ} 37^{\prime} 644^{\prime \prime}$ & $76^{\circ} 58^{\prime} 297^{\prime}$ & 1107 \\
\hline 6 & IC 597308 & E.frumentacea & Lal Sawriya & Kekdabod & $\mathrm{DN}$ & $21^{\circ} 37^{\prime} 490^{\prime \prime}$ & $76^{\circ} 56^{\prime} 954^{\prime \prime}$ & 1117 \\
\hline 7 & IC 597310 & E.frumentacea & Sawa & Tembli & $\mathrm{DN}$ & $21^{\circ} 30^{\prime} 738^{\prime \prime}$ & $76^{\circ} 54^{\prime} 557^{\prime}$, & 1100 \\
\hline 8 & IC 597315 & E. colona & Saweli ghas & Jutpani & $\mathrm{DN}$ & $21^{\circ} 30^{\prime} 762^{\prime \prime}$ & $76^{\circ} 56^{\prime} 071^{\prime \prime}$ & 1000 \\
\hline 9 & IC 597320 & E. colona & Bada Sawriya & Kara & $\mathrm{DN}$ & $21^{\circ} 30^{\prime} 372^{\prime \prime}$ & $77^{\circ} 06^{\prime} 224^{\prime}$, & 1102 \\
\hline 10 & IC 597322 & E.frumentacea & Sawriya & Lawada & $\mathrm{DN}$ & $21^{\circ} 31^{\prime} 961^{\prime \prime}$ & $77^{\circ} 01^{\prime} 496^{\prime}$ & 1295 \\
\hline 11 & IC 597323 & E.frumentacea & Safed Sawriya & Bod & $\mathrm{DN}$ & $21^{\circ} 31^{\prime} 961^{\prime \prime}$ & $77^{\circ} 01^{\prime} 496^{\prime \prime}$ & 1295 \\
\hline 12 & IC 597324 & E.frumentacea & Chota sawriya & Bod & $\mathrm{DN}$ & $21^{\circ} 31^{\prime} 792^{\prime \prime}$ & $76^{\circ} 59^{\prime} 445^{\prime}$ & 1209 \\
\hline 13 & IC 597329 & E.frumentacea & Sawan & Tingriya & $\mathrm{DN}$ & $21^{\circ} 33^{\prime} 280^{\prime \prime}$ & $76^{\circ} 52^{\prime} 025^{\prime}$ & 1093 \\
\hline 14 & IC 597336 & E.frumentacea & Sawriya & Jilpi & $\mathrm{DN}$ & $21^{\circ} 27^{\prime} 974^{\prime \prime}$ & $76^{\circ} 48^{\prime} 578^{\prime}$ & 1183 \\
\hline 15 & IC 597339 & E.frumentacea & Bhagar & Patharpur & $\mathrm{DN}$ & $21^{\circ} 26^{\prime} 595^{\prime}$ & $76^{\circ} 50^{\prime} 304^{\prime \prime}$ & 1262 \\
\hline 16 & IC 597347 & E.frumentacea & Sawa & Kamapur & $\mathrm{CK}$ & $21^{\circ} 24^{\prime} 675^{\prime}$ & $77^{\circ} 23^{\prime} 414^{\prime \prime}$ & 2935 \\
\hline 17 & D 2010-5 & E.frumentacea & Bhagar & Bahadura & $\mathrm{BP}$ & $20^{\circ} 51^{\prime} 279$ & $76^{\circ} 48^{\prime} 281$ & 879 \\
\hline 18 & IC 597289 & E. colona & Saweli ghas & Baramacha & CK & $21^{\circ} 30^{\prime} 095^{\prime \prime}$ & $77^{\circ} 31^{\prime} 373^{\prime \prime}$ & 2021 \\
\hline 19 & IC 597290 & E. colona & Saweli ghas & Amjhari & $\mathrm{CK}$ & $21^{\circ} 25^{\prime} 411^{\prime \prime}$ & $77^{\circ} 20^{\prime} 642^{\prime}$ & 2005 \\
\hline 20 & IC 597292 & E. colona & Saweli ghas & Bhawai & $\mathrm{CK}$ & $21^{\circ} 16^{\prime} 330^{\prime \prime}$ & $77^{0} 23^{\prime} 155^{\prime}$ & 2100 \\
\hline 21 & IC 597314 & E. colona & Saweli ghas & Tembli & $\mathrm{DN}$ & $21^{\circ} 31^{\prime} 497^{\prime}$, & $76^{\circ} 54^{\prime} 160^{\prime \prime}$ & 1100 \\
\hline
\end{tabular}

"Refers to Block (Chikhaldara-CK and Dharni- DN, BP- Balapur (adjoining Melghat)

ment of spikelet, degree of branching, degree of lodging, 100 seed weight etc. The data of different morphological characters is placed in Table 4 and Fig.2. The two cultivable species showed wide genetic diversity and narrow relationship with each other based on morphological characters used in the study.

Molecular diversity based on RAPD markers: In this study 20 RAPD primers were employed, out of 
M.P.Moharil et al. / J. Appl. \& Nat. Sci. 8 (3): 1643 - 1648 (2016)

Table 3. Code, sequence and nucleotide length of primers used in the RAPD analysis.

\begin{tabular}{|c|c|c|c|c|c|}
\hline S.No. & Primer code & Primer sequence 5' to 3' & Nucleotide length & $\operatorname{Tm}^{0} \mathrm{C}$ & $\mathrm{Ta}^{\mathrm{O}} \mathrm{C}$ \\
\hline 1 & OPA1 & CAGGCCCTTA & 10 -mers & 35.2 & 30 \\
\hline 2 & OPA10 & GTGATCGCAG & 10-mers & 29.8 & 26 \\
\hline 3 & OPA13 & CAGCACCCAC & 10 -mers & 34.8 & 29 \\
\hline 4 & OPA15 & TTCCGAACCC & 10-mers & 38.7 & 34 \\
\hline 5 & OPA16 & AGCCAGCGAA & 10 -mers & 40.5 & 35 \\
\hline 6 & OPA17 & GACCGCTTGT & 10 -mers & 33.7 & 28 \\
\hline 7 & OPA18 & AGGTGACCGT & 10 -mers & 31.6 & 25 \\
\hline 8 & OPA19 & CAAACGTCGG & 10 -mers & 36.6 & 32 \\
\hline 9 & OPA2 & TGCCGAGCTG & 10 -mers & 42.4 & 37 \\
\hline 10 & OPA20 & GTTGCGATCC & 10-mers & 34.2 & 29 \\
\hline 11 & OPA3 & AGTCAGCCAC & 10-mers & 26.8 & 21 \\
\hline 12 & OPA4 & AATCGGGCTG & 10-mers & 39.3 & 35 \\
\hline 13 & OPA5 & AGGGGTCTTG & 10 -mers & 31.8 & 25 \\
\hline 14 & OPA6 & GGTCCCTGAC & 10-mers & 30.8 & 25 \\
\hline 15 & OPA8 & GTGACGTAGG & 10 -mers & 22.9 & 18 \\
\hline 16 & OPA9 & GGGTAACGCC & 10 -mers & 38.7 & 34 \\
\hline 17 & OPF1 & ACGGATCCTG & 10-mers & 32.0 & 27 \\
\hline 18 & OPP10 & TGCCGAGCTG & 10 -mers & 34.0 & 29 \\
\hline 19 & OPP2 & CCCCGGTAAG & 10 -mers & 34.0 & 29 \\
\hline 20 & OPP7 & GAAACGGGTG & 10 -mers & 34.5 & 29 \\
\hline
\end{tabular}

Tm, melting temperature ;Ta, annealing temperature ; OPA series, Sigma; OPF and OPP series, Genaxy

Table 4. Morpho-agronomic traits of Echinochloa frumentacea and E. colona.

\begin{tabular}{llll}
\hline S. No. & Morphological traits & \multicolumn{2}{c}{ Echinochloa Spp. } \\
\cline { 3 - 4 } & & E. frumentacea & E. colona \\
\hline 1 & Plant height $(\mathrm{cm})$ & $70.38-115.88$ & $22.5-67.5$ \\
2 & Leaf length $(\mathrm{cm})$ & 18.07 & 15.7 \\
3 & Leaf width $(\mathrm{cm})$ & 0.65 & 0.6 \\
4 & Flag leaf length $(\mathrm{cm})$ & 15.6 & 6.2 \\
5 & Flag leaf width $(\mathrm{cm})$ & 1.0 & 0.25 \\
6 & Inflorescence length $(\mathrm{cm})$ & 10.39 & 6.75 \\
7 & Inflorescence width $(\mathrm{cm})$ & 1.8 & 0.3 \\
8 & Number of racemes/inflorescence & 16.0 & $5.0-6.0$ \\
9 & Raceme length $(\mathrm{cm})$ & 1.7 & 1.5 \\
10 & Colour of inflorescence & Green & Green \\
11 & Days to maturity & $78-98$ & $50-60$ \\
12 & Inflorescence shape & Elliptical & Straight \\
13 & Inflorescence compactness & Intermediate & Open \\
14 & Shape of lower raceme & Straight/slightly curved & Straight \\
15 & Length of peduncle $(\mathrm{cm})$ & 10.3 & 11.0 \\
16 & Arrangement of spikelet & Round the axis & One side \\
17 & Degree of branching & Low-medium-high & Low \\
18 & Degree of lodging & Low & Intermediate \\
19 & Seed shattering & Low & High \\
20 & 100 seed weight $(\mathrm{g})$ & $0.25-0.37$ & $0.11-0.13$ \\
21 & Seed colour & White & White \\
\hline
\end{tabular}

which 11 primers revealed polymorphism and were used for further analysis. Polymorphic primers detected 5 to 9 bands with an average of 7 bands from each accession (Table 5). Genetic diversity among 21 accessions was calculated on the basis of DNA fingerprints generated with a set of 11 oligo-decamer primers using UPGMA method based on 'Jaccard's' similarity coefficient. Based on the similarity index, genetic dis- tance values were calculated and used to construct the dendrogram (Fig.1). Among the 21 genotypes, similarity ranged from 67.28 to $94.0 \%$. Two major groups (A and B) were formed, at $67.28 \%$ similarity, which clearly encompasses 15 accessions of E. frumentacea and 6 accessions of E. colona (Fig.1). Further, the group of $E$. frumentacea was divided into two major clusters $\left(\mathrm{A}_{1}\right.$ and $\left.\mathrm{A}_{2}\right)$ also E. colona was divided into 
M.P.Moharil et al. / J. Appl. \& Nat. Sci. 8 (3): 1643 - 1648 (2016)

Table 5. RAPD analysis for 21 Barnyard millet accessions using the following primers.

\begin{tabular}{llllll}
\hline S.No. & Primer & Size of fragments(bp) & $\begin{array}{l}\text { Total no. } \\
\text { fragments }\end{array}$ & $\begin{array}{l}\text { Number of polymor- } \\
\text { phic fragments }\end{array}$ & $\begin{array}{l}\text { Percent phic loci } \\
\text { phic }\end{array}$ \\
\hline 1 & OPP2 & $200-1000$ & 6 & 4 & 66.66 \\
2 & OPP10 & $200-700$ & 5 & 4 & 80.00 \\
3 & OPP7 & $150-600$ & 5 & 3 & 60.00 \\
4 & OPA13 & $200-1000$ & 7 & 5 & 71.42 \\
5 & OPA4 & $200-900$ & 9 & 8 & 88.88 \\
6 & OPA3 & $100-600$ & 6 & 4 & 66.66 \\
7 & OPA6 & $150-700$ & 6 & 5 & 83.33 \\
8 & OPA5 & $200-850$ & 5 & 3 & 60.00 \\
9 & OPA2 & $200-1000$ & 5 & 4 & 80.00 \\
10 & OPA18 & $150-900$ & 7 & 6 & 85.71 \\
11 & OPF1 & $100-600$ & 6 & 4 & 66.66 \\
\hline Total & & $\mathbf{6 7}$ & $\mathbf{5 0}$ & $\mathbf{7 4 . 6 2}$ \\
\hline
\end{tabular}

OPA4

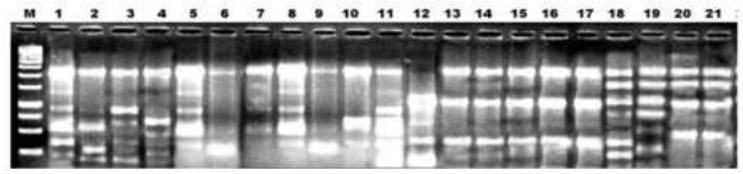

OPP10

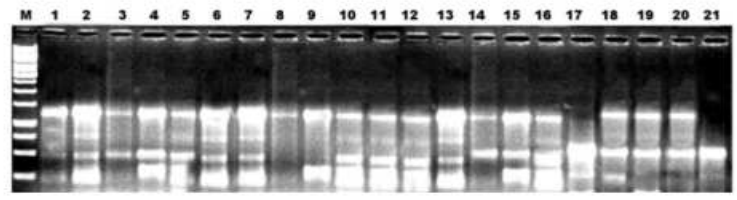

OPA13

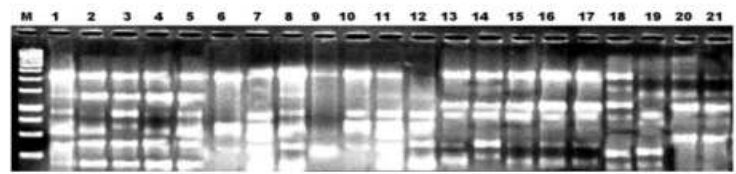

OPA3

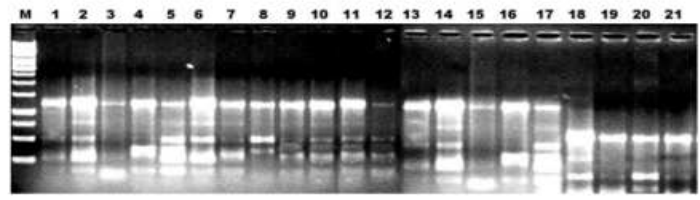

Plate 1. (a) Barnyard millet (Echinochloa frumentacea (Roxb.) Link).(b) Amplification profile of 21 Barnyard millet accessions using RAPD primers, $M=$ DNA ruler plus, numbers on top are accessions as given in Table 2.

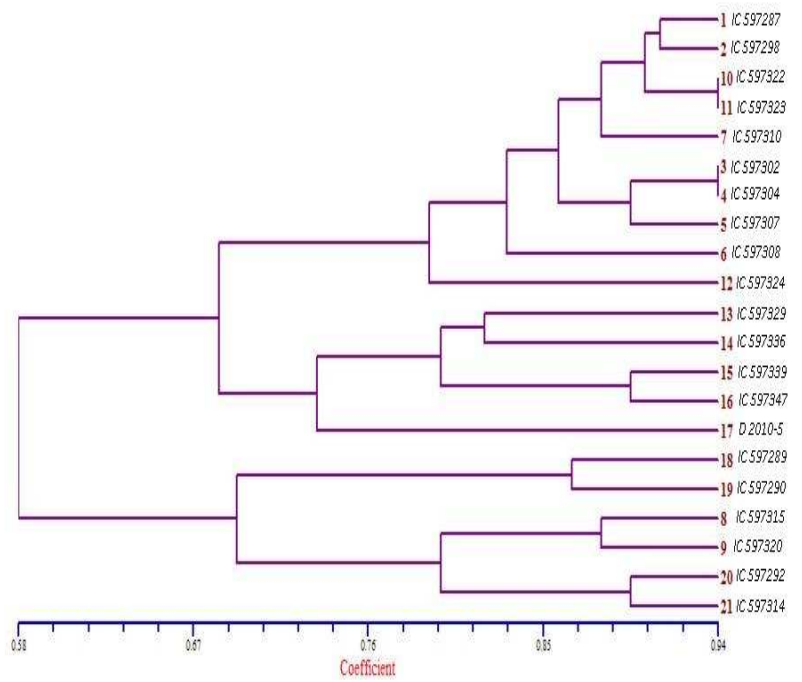

Fig. 1: Random amplified polymorphic DNA cluster analysis of fingerprint patterns generated with a set of 11 oligodecamer primers from genomic DNA of 21 accessions belonging to two cultivable species of Barnyard millet (Echinochloa colona and Echinocloa frumentacea) on the basis of banding pattern. The unweighted pair-group method, arithmetic mean (UPGMA) algorithm was applied using computer software NTSYS-pc software ver. 2.02. two major clusters $\left(\mathrm{B}_{1}\right.$ and $\left.\mathrm{B}_{2}\right)$. Higher similarity was observed in accessions of $E$. frumentacea, i.e. up to 94\%. The accessions IC 597322 and IC 597323 also IC 597302 and IC 597304 showed more than $94 \%$ similarity among themselves. Greater similarity among $E$. frumentacea may be due to repeated cultivation of same genotypes year after year, inbreeding nature of the crop and/or due to the collection of the accessions from a small area.

Similarity observed among accessions of E. colona was less than that of $E$. frumentacea i.e up to $88.8 \%$. This clearly indicates the wild biological nature of the species. The similarity index showed about $32.8 \%$ diversity between two species. Polymorphism in RAPD markers has been reported in barnyard grass (Echinochloa crusgalli) (Roy et al., 2000).

The two species E. frumentacea and E. colona differ in inflorescence morphology, plant height, leaf length, leaf width, flag leaf length, flag leaf width, inflorescence length, inflorescence width, number of racemes / inflorescence, raceme length, colour of inflorescence, days to maturity, inflorescence shape, inflorescence compactness, shape of lower raceme, length of peduncle, arrangement of spikelet, degree of branching and degree of lodging etc. 


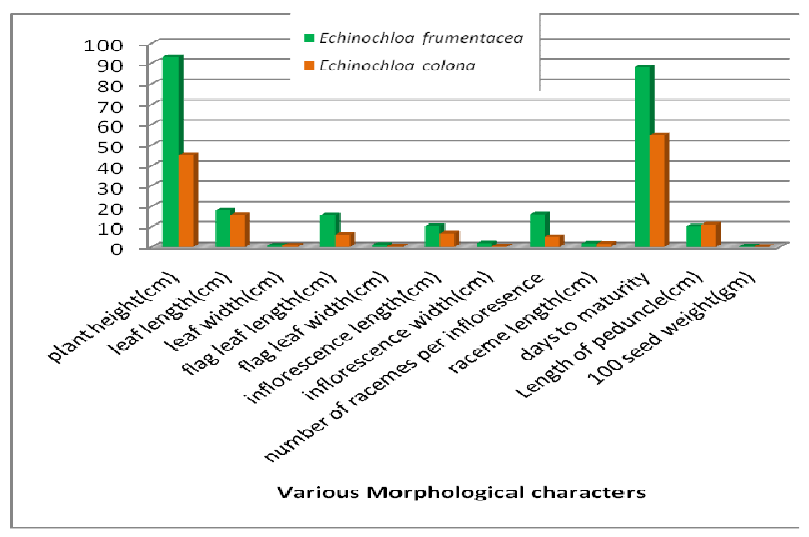

Fig. 2. Comparison of morphological characters between the two species.

The classification of genetic diversity has enabled clear-cut grouping of barnyard millet accessions into two morphological races. Two species of barnyard millet are showing wide genetic diversity. Accessions of $E$. colona showed more genetic diversity within species on the basis of RAPD molecular markers. Also some accessions of $E$. frumentacea showed more than $90 \%$ similarity, which allows breeders and farmers for precise selection of better genotype for cultivation. The genetic similarity of the E frumentacea and E. colona samples correlated with their close geographic locations. This phenomenon was also observed in the morphological characteristics of barnyard grass (Echinochloa crusgalli ) in Indonesia (Tasrif, et al., 2003).

Studies on genetic diversity analysis are important in detailing the level of variation and relationship within and between species depending on their geographical location as small millet species are important in view of food and fodder requirement of the native tribal people.

The study can also prove helpful to the farmers in selecting cultivars for greater yields in diverse agronomic conditions. In the context of increasing demand of nutritional crops and ever increasing cases of diabetic and other metabolic disorders, the need of the hour is to make millet farming more lucrative and popular. Melghat biosphere reserve is a rich source of genetic diversity of several millets. Small millet species are important in view of food and fodder requirement of the native Korku and Gond tribal people. Barnyard millet is of high importance in tribal people due to its drought tolerance, good yield and superior nutritional value. Also efforts are to be made in multilocation evaluation of barnyard millet germplasm for high yielding genotypes along with its nutritive characterisation from diverse geographic locations for its proper utilization in crop improvement programmes.

\section{Conclusion}

A high degree of molecular diversity among the landraces was detected for barnyard millet. Among the 21 genotypes, two major groups (A and B) were formed, at $67.28 \%$ similarity, which clearly encompassed 15 accessions of $E$. frumentacea and 6 accessions of $E$. colona. Higher similarity was observed in accessions of E. frumentacea. The accessions IC 597322 and IC 597323 also IC 597302 and IC 597304 showed more than $94 \%$ similarity among themselves. It enabled clear-cut grouping of barnyard millet accessions into two morphological races (E. frumentacea and E. colona). The study may be helpful to the farmers in selecting millet cultivars for greater yields in diverse agronomic conditions.

\section{REFERENCES}

Doyle, J. J., and Doyle, J. L. (1990). Isolation of plant DNA from fresh tissue. Focus, 12: 13-15

Doyle, J. J., and Doyle, J. L. (1987). A rapid DNA isolation procedure for small quantities of fresh leaf tissue. Phytochem Bulletin, 19:11-15

Gupta, A., Mahajan, V., Mukesh Kumar and Gupta, H. S. (2009). Biodiversity in the barnyard millet (Echinochloa frumentacea Link, Poaceae) germplasm in India. Genetic Resources Crop Evolution, 56:883-889

Holm L.G., Plucknett D.L., Pancho J.V., and Herberger J.P. (1977). The World's Worst Weeds. Distribution and Biology. (Universiti Press,Honolulu, Hawaii).

Linacero, R.J., Rueda and vazquez A.M. (1998). Quantifying of DNA. Karp, A., P.G. Isaac, and D.S. Ingram (eds.) Molecular tools for screening biodiversity: plants and animals. Chapman and Hall. London, Weinheim, New york, Tokyo, Melbourne, Mmadras. pp. 18-21.

Michael, P.W. (1994). Distribution and taxonomy of Echinochloa - A world view with a key to the species occurring in China. Proceedings of the 5th Weed Science Conference of China, pp. 161-6.

Roy, S., Simon, J. P., and Lapointe, F. J. (2000). Determination of the origin of the cold adapted population of barnyard grass (Echinochloa crus-galli) in eastern North America: A total evidence approach using RAPD DNA and DNA sequences. Canadian Journal of Botany, 78: 1505-1513.

Sambrook, J., Frilsch, E. F., and Maniatis, T. (1989). Molecular Cloning: A Laboratory Manual. 2nd Edn. Cold spring Harbor Laboratory Press, Cold Spring Harbor, N.Y.

Tasrif, A., Juraimi, A. S., Kadir, J., Napis, S. and Sastroutomo, S. S. (2003). Morphological and molecular variation among Indonesian ecotypes of barnyardgrass (Echinochloa crus-galli var. Crusgalli L. Beauv). In Proceeding of the $15^{\text {th }}$ Conference of Indonesian Weed Science Society.

Ugare, R., Chinmad, B., Naik, R., Bharati, P. and Itagi, S. (2011). Glycaemic index and significance of barnyard millet (Echinochloa frumentacea) in type II diabetes. Journal of Food Science and Technology, DOI:10.1007/s13197-011-0516-8.

Watson, L. and Dallwitz, M.J. (1992). 'The grass genera of the world'. (CAB International, Oxford, UK).

Yabuno, T. (1962). Cytotaxonomic studies on the two cultivated species and the wild relatives in the genus Echinochloa. Cytologia, 27:296-305. 